\title{
The Effect of Public Service Quality on Equity Satisfaction in Indigenous People Batak Simalungun
}

\author{
${ }^{1 \text { st }}$ Pratiwi Nurhabibi ${ }^{1},{ }^{2 n d}$ Dasman Lanin ${ }^{2},{ }^{3 r d}$ Boni Saputra ${ }^{3}$ \\ \{pratiwi@fis.unp.ac.id ${ }^{1}$, dasman@fis.unp.ac.id ${ }^{2}$, bonisaputra@fis.unp.ac.id ${ }^{3}$ \} \\ Department of Public Administration, Universitas Negeri Padang, Padang, Indonesia ${ }^{1,2,3}$
}

\begin{abstract}
The success of government administration in public services is measured by achieving public satisfaction. Community satisfaction is largely determined by Total Quality Management (TQM) based services. However, in the management of local government services for TQM-based satisfaction, it is still not a complete solution level. Therefore this study will examine a satisfactory service model (equity satisfaction) in the context of TQM with the background of the local wisdom of the indigenous Batak Simalungun people. The purpose of this study is to analyze the influence of the quality of public services on equity satisfaction in the indigenous Batak Simalungun. The method used in this research is quantitative by using purposive sampling. The sample was taken as many as 200 people. The data analysis in this study is regression. As a result, there is a significant influence between the quality of public services on equity satisfaction in the original Batak Simalungun community.
\end{abstract}

Keywords: Satisfaction, Equity, Public Services, Indigenous People

\section{Introduction}

The government has the main role as a public servant, so it is morally obliged to continue to strive to improve the quality of service itself. The measure of the success of service delivery is determined if the community receives services that are needed and expected. Of course, this is based on normative values regarding public services as stipulated in Law Number 25 of 2009 Article 1 Paragraph (1) which states that public services are activities or series to fulfill service needs in accordance with statutory regulations for each citizen and residents of the goods, services, and/or administrative services provided by public service providers. Based on this definition, the fulfillment of public service activities has been regulated based on regulations made by the government with the main objective of meeting the basic needs and welfare of the community. Service standards are benchmarks that are used as guidelines for service delivery and reference for assessing service quality as obligations and promises of providers to the public in the framework of quality, fast, easy, affordable and regular service. The existence of Law Number 25 of 2009 concerning Public Services certainly provides direction to all service providers, both state administrators, BUMN, BUMD, BHMN to the private sector, and individuals providing standardized services by fulfilling standard service components. 
Astari (2019) states that a bureaucracy will succeed or not in providing services that have many factors including cultural factors, individual factors as well as organizational and management factors [1]. Therefore, in the context of organizational theory, every organization, including public organizations such as the bureaucracy, has a role as stated in the Law of the Republic of Indonesia No. 43 of 1999 concerning Personnel Principles Article 12 (2000: 6), one of the points, states: "The management of civil servants is directed to ensure the efficient and effective implementation of government and development tasks." The state apparatus as the executor holds a very heavy task, where there are challenges and obstacles to be faced.

Although regulations on public services have been regulated in Law Number 25 of 2009 and the emphasis in the 1945 Constitution regarding the state's responsibility to meet the basic needs of its people, there are still many problems in fulfilling the quality of public services by local governments. Lanin's research (2010) found that the satisfaction of residents of Padang Panjang with the city government, in providing services for the basic needs of citizens (education, health, and social welfare), was generally in negative confirmation. The same thing was also found in the Saputra (2016) study that the community was not satisfied with the indicator of service time at the Kampar District Mining District Office because often the time for taking the identity card or the finished permit was not according to the predetermined collection schedule[4]. The low quality of public services provided by government officials is a bad image of the government in society. Some people who have dealt with bureaucracy always complain and are disappointed with the services provided.

The Ombudsman in 2019 received 7,903 public reports. Public complaints regarding maladministration of protracted delays still dominate, namely $33.62 \%$ or as many as 1,837 complaints. Followed by procedural deviations of $28.97 \%$ or 1,583 reports, and not providing services for $17.7 \%$ or 967 complaints. The low compliance of Regional Apparatus Organizations (OPD) to the implementation of Public Service Standards is the main obstacle to the quality of service in all government agencies. The low compliance/implementation of Service Standards resulted in various types of subsequent maladministration dominated by apparatus behavior, such as unclear procedures, the uncertainty of service tenure, illegal fees, corruption, uncertainty in investment licensing services, arbitrariness, and at a macro level resulted in low quality of public services. This results in a high-cost economy, barriers to investment growth, and of course has an impact on decreasing public trust in the apparatus and government which has the potential to lead to public apathy. The result is corruption, bureaucratic inefficiency, and low quality of public services. Therefore, a service standard is needed as an instrument to be used as a guideline for service delivery and a reference for assessing service quality as an obligation and promise of service providers to the public to provide quality, fast, easy, affordable, and measurable services. (Law Number 25 of 2009, articles 20-21).

Problems related to the poor performance of local government in the field of public services also occurred in six regions in North Sumatra Province. This assessment has been carried out by the Indonesian Ombudsman since May 2019. This assessment is based on a survey of compliance with public service standards carried out in 13 districts and city governments in North Sumatra. The area with the worst public service is Simalungun Regency with the lowest score of 9.25 . Followed by the South Nias Regency Government with a score of 16.82, the Padangsidimpuan City Government with a value of 31.81, the Labuhanbatu Regency Government with a score of 35.39 , the Asahan Regency Government with a value of 42.83 , the last is the Karo Regency Government with a value of 47.20. 
However, in the results of research Astari (2019) states that the success factor of a bureaucracy in providing services, one of which is the local cultural approach[1]. The use of local wisdom in public services can actually be the basis for common political interests so as to boost cultural values in the bureaucracy. Local wisdom from ethnic culture as the basis for providing public services is the main source in building the mental soul of public service implementers. Lanin's research (2006) found that people throughout Minangkabau nagari feel more comfortable being managed with ethnic cultural values compared to top-down management by the government. Research by Wiryawan, et al. (2018) also revealed that the values of Balinese local wisdom are appointed as a guarantee for the accountability of public officials as the main actors of public services[8].

Seeing the description of some of the phenomena above, the researcher is moved to examine whether the quality of service in the tourism and culture offices affects equity satisfaction in Batak Simalungun indigenous people.

\section{Methodology}

The research was conducted at the Department of Tourism and Culture of Simalungun Regency and was carried out in August-September 2020. The method used in this research was quantitative using purposive sampling. The research subjects were 200 people of the Batak Simalungun tribe. The data analysis in this study is regression. In conducting this research, the data used are primary. The data was collected using a research instrument in the form of a questionnaire, which was carried out by distributing a list of statements to respondents and then measured using a Likert scale. The validity and reliability of the questionnaires that were distributed previously had been tested. Validity testing is carried out using the Pearson Product Moment correlation with a correlation coefficient $\geq$ of 0.3 , so the instrument items are declared valid. A reliability test is also conducted to determine the consistency of measuring instruments used so that if the measuring instrument is used again to examine the same object with the same technique even though the time is different, the results will be the same. An instrument is said to be reliable if it has a Cronbach Alpha value $\geq 0.60$ (Hair et al., 2010). The service model has six Service Transaction variables (1) delivery, (2) timeliness, (3) professionalism, (4) staff attitude, (5) available information, and (6) organization politic (the state of the organization's internal politics).

\section{Finding And Discussion}

Statistical data processing in this study was carried out using regression analysis. Previously, the data had already been tested for the classical assumptions prerequisites. The classical assumption test includes 1) normality test; 2) linearity test; 3) heteroscedasticity test; and 4) multicollinearity test. The classical assumption test analysis is proven to meet the requirements and has passed the prerequisite test so that the data is declared worthy of analysis at the next stage, namely the regression test. The results of the regression test can be seen in the table below: 
Table 1. Regression Test Results

\begin{tabular}{llccc}
\hline \multicolumn{1}{c}{ Model } & R & R Square & $\begin{array}{c}\text { Adjusted R } \\
\text { Square }\end{array}$ & Sig. \\
\hline $\begin{array}{l}\text { The influence of public service quality on equity satisfaction } \\
\text { in Batak Simalungun indigenous people }\end{array}$ & $.591^{\mathrm{a}}$ & .349 & .346 & .000 \\
& & & &
\end{tabular}

Source: Research Results 2020 (data processed)

Based on the table above, it can be seen the influence and the magnitude of the contribution of exogenous variables to endogenous variables. The results of the statistical data processing test prove that exogenous variables are proven to have a significant effect on job satisfaction at the Culture and Tourism Office of Simalungun Regency. This is evidenced by the acquisition of a significant value which is below $<0.05$. The significance here also means that the effect of each exogenous variable on the endogenous variable has a real and significant effect.

Engel (Tjiptono, 2004: 147) defines customer satisfaction as a full evaluation of the chosen alternatives that give the same results or exceed customer expectations. Described by Linder Pelz in Gotleb, Grewal, and Brown (Tjiptono 2004: 147), that satisfaction is an effective response to a specific consumption experience[6].

From the results of data processing and data analysis, it can be decided that the hypothesis which states that there is an effect of performance on the satisfaction of the Batak Simalungun Community Equity is proven. Based on the test results, it shows the coefficient of determination (R2) of 0.346 , the significance value of 0.000 , with the beta coefficient having a positive value for the variable quality of public services. So it can be interpreted that $34.6 \%$ of the effect of significant positive changes in the satisfaction variable of Batak Simalungun community equity is influenced by the variable quality of public services. The results of this study are also the same as the results of research conducted by Nirwana (2019) and Astari (2019) which prove that employee performance has a significant effect on job satisfaction[3]. Employee performance significantly encourages the achievement of a level of community satisfaction, if the performance of these employees is also able to improve the quality of services provided to the community. (Maryani, 2013).

The satisfaction of the community is also based on the ethnic similarity factor of most of the employees at the Tourism and Culture Office of Simalungun Regency. The apparatuses understand the character of the people in Simalungun, so that they are able to communicate properly with the public so that services can run effectively.

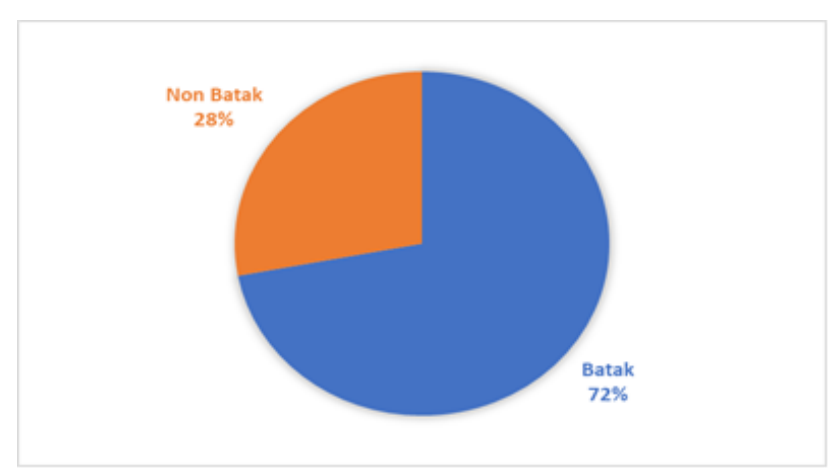

Fig. 1. Ethnic of The Staff 
In diagram 1. above we can see that the percentage of the number of employees with Batak ethnicity is more, which is $72 \%$ compared to non-Batak, which is $28 \%$. This means that with the existence of ethnic equality between employees and the local community, a close enough social relationship can be established so that it will be easy to carry out development programs including public services.

The Simalungun ethnic cultural approach is needed in public services. Some of the philosophies of the Simalungun ethnic community include "sapangambei manoktork hitei", which means "working together to achieve goals for the common interest of achieving prosperity" and "sadani riah do parsautni horja, parsautni horja do pardasni sura-sura" which means "deliberation is the beginning of the event. a job, if work happens then dreams happen. "The government should understand these philosophical values as policy makers so that in determining programs it must touch the community.[5]

The effect of developing the idea of democratization in government or public sector services is that accountability is not only internal to public organizations, but also externally; community, public and citizens (not only consumers, customers or users, but includes citizens as a whole). The government has changed its paradigm from state oriented to public oriented, which was originally implemented the concept of pamong and ambtenar serving their masters, transformed into servants to their citizens, initially state servants and power turned into servants of society and the people which lead to the creation of satisfaction, trust and public voice or participation politics. [7]

The government as the activator and implementer of development requires apparatus who can work effectively and efficiently to achieve the stated national development goals. Today, one of the biggest challenges faced by the government, especially the regional government is how to display good apparatus, have a high work ethic, competitive advantage, and the ability to uphold the bureaucracy in carrying out its duties and functions and fulfill the aspirations of the community and be free from collusion, corruption, and nepotism. This challenge is reasonable considering that, empirically, the people in the area want the government apparatus in carrying out their duties to work optimally which in turn can provide the best service to the community [1].

\section{Conclusion}

The purpose of this study was to determine the effect of public service quality on the satisfaction of the Simalungun Batak ethnic community. The public agency studied was the Culture and Tourism Office of Simalungun Regency. After conducting research, data processing, and discussion, in this study, it can be concluded that there is a significant influence between the quality of public services on equity satisfaction in the indigenous people of Batak Simalungun.

Through this research, it is also suggested to the Department of Culture and Tourism of Simalungun Regency that in increasing the satisfaction of community equity, employees as public servants should be able to provide the best quality service in accordance with what has been programmed by the government and applicable regulations.

\section{Acknowledgment}

Thanks to the Institute for Research and Community Service (LP2M), Universitas Negeri Padang for the assistance of PNBP research funds for the 2020 fiscal year. The author also thanks Prof. Dasman Lanin as the supervisor in this research, the government of the 
Simalungun Regency Culture and Tourism Office, the people in Simalungun Regency who supported this research well, and thanks to the research team, for the cooperation and assistance of all parties, finally this research can be completed on time.

\section{References:}

[1] Astari I. Pengaruh Kinerja Pegawai Terhadap Kepuasan Masyarakat Di Kantor Kecamatan Linggang Bigung Kabupaten Kutai Barat. Administrasi Publik. 2019 Mar 8;2(3):1721-6.

[1] Hair, Jr., Et Al., (2010).Multivariate Data Analysis ( $7^{\text {th }}$ Ed). United States: Pearson.

[2] Lanin D, Mabarak A. Kepuasan Diskonfirmasi Warga Pada Sektor Publik: Kasus Pelayanan Kebutuhan Dasar Pemerintahan Kota Padangpanjang. Jurnal Demokrasi. 2010 Oct $1 ; 9(2)$.

[3] Nirwana M. Pengaruh Kinerja Pegawai Terhadap Kepuasan Masyarakat Pada Dinas Perpustakaan Dan Kearsipan Daerah Provinsi Kalimantan Timur. Administrasi Publik. 2019 Nov 21;2(4):2280-6.

[4] Saputra T. Kepuasan Masyarakat Terhadap Penyelenggaraan Pelayanan Publik (Studi Kasus Kantor Kecamatan Tambang Kabupaten Kampar). Jurnal Perspektif Pembiayaan Dan Pembangunan Daerah. 2016;4(2):89-100.)

[5] Saragih, H. (2018). Dinamika Identitas Etnis Simalungun Dan Pembangunan Di Kota Pematang Siantar. Etnohistori: Jurnal Ilmiah Kebudayaan dan Kesejarahan, 5(2), 185 196.

[6] Tjiptono, Fandy, 2004. Strategi Pemasaran Edisi Kedua, Penerbit Andi Offset, Yogyakarta.

[7] Vigoda-Gadot, E. 2006. "Citizens"e Perceptions Of Politics And Ethics In Public Administration: A Five-Year National Study Of Their Relationship To Satisfaction With Services, Trust In Governance, And Voice Orientations" Dalam Journal Of Public Administration Research And Theory, Volume 17, Oxford University Press

[8] Wiryawan IW, Perbawa IK, Julianti L. Inovasi Pelayanan Publik Berbasis Teknologi Informasi Dan Komunikasi Berdasarkan Nilai Kearifan Lokal Bali. Jurnal Advokasi. 2018 Dec 22;8(1):87-100.

[9] Undang-Undang Nomor 25 Tahun 2009 Tentang Pelayanan Publik

[10] Undang-Undang Republik Indonesia No. 43 Tahun 1999 Tentang Pokok-Pokok Kepegawaian 